\title{
Biodiversitas Zooplankton di Perairan Pesisir Pulau Keffing pada Musim Peralihan II, Kabupaten Seram Bagian Timur
}

\author{
Hanung Agus Mulyadi1* dan Johanis Lekalette ${ }^{2}$ \\ 'Laboratorium Plankton, Pusat Penelitian Laut Dalam, Lembaga Ilmu Pengetahuan Indonesia \\ 2Laboratorium Fisika Oseanografi, Pusat Penelitian Laut Dalam, \\ Lembaga Ilmu Pengetahuan Indonesia \\ Jl. Y. Syaranamual, Guru-guru Poka, Ambon, Maluku 97233 \\ Email: hanu001@lipi.go.id
}

\section{Abstract \\ Biodiversity of Marine Zooplankton in Coastal Area of Keffing Island During Transitional Season II, East Seram Regency}

\begin{abstract}
Zooplankton has an important role in thropic ecology at coastal area. According to their ecological function as the first consumer, zooplankton linked between producers (phytoplankton) and other marine organisms in the higher thropic level. The abundance of zooplankton in coastal area can be indicate as secondary productivity and as a food source for fisheries. This study aims to examine the biodiversity of zooplankton in coastal area of Keffing Island, Eastern Seram regency. Sampling was conducted in November 2017 during November (transitional season II) using NORPAC net (mesh size 300 micrometer) with vertical hauling from 10 meter of deep to the surface water. Samples were preserved with $4 \%$ formaldehyde and identify in the laboratory. The results showed that the biodiversity of zooplankton during transitional season II was 28 species, which copepods are the dominant taxa (13 species, $46.43 \%$ of total zooplankton). The total abundance of zooplankton is 351-1190 individu/m33, which Oncaea sp, Eucalanus sp and Corycaeus sp are abundant. Study biodiversity in coastal area of Keffing Island is important to support fisheries management programs. Avalaibility of data on the composition and abundance of zooplankton can be used as baseline data of secondary productivity and potency of natural food source in coastal area.
\end{abstract}

Keywords: Zooplankton; Copepods; Keffing Island; East Seram Regency

\begin{abstract}
Abstrak
Zooplankton mempunyai peranan penting dalam jejaring ekologi perairan pesisir. Posisinya sebagai konsumen pertama akan menghubungkan antara produsen dalam hal ini fitoplankton dengan biota pada tingkat tropik level di atasnya. Kelimpahan zooplankton di suatu perairan dapat menggambarkan produktivitas sekunder dan potensialitas pakan alami dari sumberdaya perikanan di suatu perairan. Penelitian ini bertujuan untuk mengkaji biodiversitas zooplankton di perairan pesisir Pulau Keffing, Seram Bagian Timur (SBT). Penelitian ini dilakukan pada bulan November 2017 (musim peralihan II). Pengambilan sampel dilakukan dengan menggunakan jaring NORPAC (mata jaring 300 mikrometer), ditarik secara vertikal dari kedalaman 10 meter menuju permukaan. Sampel dipreservasi menggunakan formalin $4 \%$, dan diidentifikasi di laboratorium. Hasil penelitian menunjukkan bahwa biodiversitas zooplankton selama musim peralihan II sebanyak 28 jenis. Komposisi jenis copepoda mendominasi dengan 13 jenis $(46,43 \%$ dari total komposisi zooplankton). Kelimpahan Total zooplankton berkisar antara $351-1190 \mathrm{ind} / \mathrm{m}^{3}$. zooplankton yang melimpah dari jenis Oncaea sp., Eucalanus sp. dan Corycaeus sp. Kajian tentang biodiversitas zooplankton di pesisir Pulau Keffing sangat penting untuk mendukung program pengelolaan sumberdaya perikanan. Ketersediaan data komposisi dan kelimpahan zooplankton dapat digunakan sebagai data dasar produktivitas sekunder dan potensi pakan alami di perairan.
\end{abstract}

Kata Kunci: Zooplankton; Copepoda; Pulau Keffing; Kabupaten Seram Bagian Timur 


\section{PENDAHULUAN}

Kabupaten Seram Bagian Timur (SBT) merupakan kabupaten dengan ciri bahari yaitu $72 \%$ wilayahnya adalah lautan. Wilayah ini berada pada lintang tropis serta berbatasan dengan Laut Seram, Laut Banda dan Laut Arafura. Hal ini menyebabkan Kabupaten SBT kaya akan potensi sumberdaya perikanan. Salah satu kecamatan yang memiliki potensi sumberdaya perikanan yang potensial adalah Kecamatan Seram Bagian Timur.

Kecamatan Seram Bagian Timur memiliki area seluas $73.35 \mathrm{~km}^{2}$ atau sekitar 1,27 persen dari seluruh luas daratan Kabupaten SBT. Kecamatan ini terdiri dari 28 pulau, namun dari pulau-pulau tersebut hanya 8 pulau saja yang berpenghuni. Kecamatan Seram Timur beribukota di Geser, memiliki 6 negeri, 10 negeri administratif, dan 33 dusun (BPS Kab Seram Bagian Timur, 2018). Lebih lanjut dijelaskan bahwa keseluruhan areanya merupakan daerah pesisir sehingga kehidupan masyarakat di Kecamatan Seram Timur sangat bergantung pada laut.

Hasil perikanan dari Kecamatan Seram Timur selama tahun 2017 sebesar 8278 ton (BPS Kab Seram Bagian Timur, 2018). Tingginya nilai produksi hasil perikanan perlu didukung dengan data potensialitas pakan alaminya, dalam hal ini adalah kelimpahan plankton. Keberadaan plankton di suatu perairan juga menjadi penanda tingkat kesuburan perairan. Sebagai konsumen pertama dari proses rantai makanan, zooplankton berperan sebagai penghubung antara produsen (fitoplankton) dan biota laut pada tingkat tropik yang lebih tinggi seperti ikan-ikan pemakan plankton (planktivorous fishes). Dalam rantai makanan, ikan ikan pemakan plankton yang biasanya termasuk dalam kelompok ikan pelagis kecil, akan menjadi makanan utama ikan yang bersifat karnivora seperti Tuna dan Cakalang. Sanchez-Velasco \& Sirhasago (2000) menjabarkan tentang kebiasaan makan larva ikan scomber japonicus yang mengkonsumsi plankton dari jenis Penilia (Kladosera), naupli kopepoda dan diatom. Lebih lanjut, Verala et al., (2017) menginformasikan bahwa juvenil ikan Tuna ekor kuning (Thunus albacares) yang merupakan tipe ikan karnivora mengkonsumsi jenis-jenis ikan epipelagik kecil (96, 86\%), Chepalopoda (3,29\%) dan Crustasea $(0,003 \%)$. Terlihat bahwa pada serangkaian tropik ekologis jejaring makanan di pesisir dan laut, zooplankton berperan penting dalam proses transfer energi pada biota dengan tingkat tropik yang lebih tinggi yaitu pada sumberdaya perikanan pelagis kecil (small pelagic fishes) maupun ikan-ikan karnivora, salah satunya ikan Tuna yang mengkonsumsi ikan pelagis kecil sebagai sumber makanan utamanya. Namun demikian, belum ada kajian tentang kondisi komposisi dan kelimpahan plankton di sekitar Pulau Keffing. Penelitian ini bertujuan untuk mengkaji biodiversitas zooplankton pada musim peralihan II (MP II) di Pesisir Pulau Keffing. Sehingga diharapkan dapat menjadi landasan ilmiah bagi stakeholders terkait dalam membuat strategi pengelolaan sumberdaya perikanan pelagis kecil di pesisir Pulau Keffing.

\section{MATERI DAN METODE}

Penelitian ini dilakukan sebanyak 5 (lima) stasiun di perairan pesisir Pulau Keffing, Seram Bagian Timur (Gambar 1). Pengambilan sampel zooplankton dilakukan dengan menggunakan jaring NORPAC (Ukuran mata jaring 300 mikron, diameter mulut jaring $0,45 \mathrm{~m}$ ) yang dilengkapi dengan flow meter. Jaring ditarik secara vertikal dari kedalaman 10 meter ke permukaan.

Sampel yang diperoleh dimasukkan ke dalam botol sampel yang telah diberi formalin hingga konsentrasi akhir perbandingan air laut dan sampel menjadi 4 \% (Omori \& Ikeda, 1984). Sampel plankton kemudian diidentifikasi menggunakan beberapa pustaka (Yamaji, 1984; Hutabarat \& Evans, 1986; Mulyadi 2004). Pengamatan dilakukan di laboratorium Plankton, Pusat Penelitian Laut Dalam-Lembaga IImu Pengetahuan Indonesia.

Pengukuran parameter pendukung yang meliputi kondisi oseanografis perairan (suhu, salinitas, klorofil-a fluorescent, turbiditas, sigma-T) dilakukan dengan menggunakan CTD Alex. Rekaman profil CTD dari permukaan laut hingga kedalaman 
maksimum $75 \mathrm{~m}$ dilakukan dengan laju turun $0,25 \mathrm{~m} / \mathrm{s}$ untuk mendapatkan struktur data yang halus. Lapisan massa air diidentifikasi dari perubahan temperatur per kedalaman atau gradien temperatur $\partial T / \partial z$, dimana $\partial T$ adalah perubahan temperatur dalam ${ }^{\circ} \mathrm{C}$ dan $\partial z$ adalah perubahan kedalaman dalam meter. Kedalaman lapisan tercampur mempunyai gradien temperatur kurang dari $0,05^{\circ} \mathrm{C} / \mathrm{m}$ dan yang lebih besar dari $0,05^{\circ} \mathrm{C} / \mathrm{m}$ adalah lapisan termoklin (Bureau of technical supervision of the P.R of China, 1992). Analisa grafik dan penampang menegak dibuat menggunakan perangkat lunak ODV (Ocean Data View) dan Surfer 9. Dilakukan analisa PCA (Principal Component Analysis) terhadap parameter fisika oseanografis untuk menggambarkan informasi yang mudah dipahami dengan hanya menarik informasi penting. Hasil analisa PCA dapat menunjukkan korelasi antar parameter pada setiap stasiun.

\section{HASIL DAN PEMBAHASAN}

Berdasarkan hasil identifikasi, diperoleh total sebanyak 28 jenis zooplankton (termasuk telur dan juvenile copepoda serta telur ikan). Komposisi zooplankton secara lebih rinci tersaji pada Tabel 1.

Berdasarkan Tabel 1, terlihat bahwa komposisi total zooplankton tertinggi di Stasiun 4 dengan 18 jenis, di posisi kedua

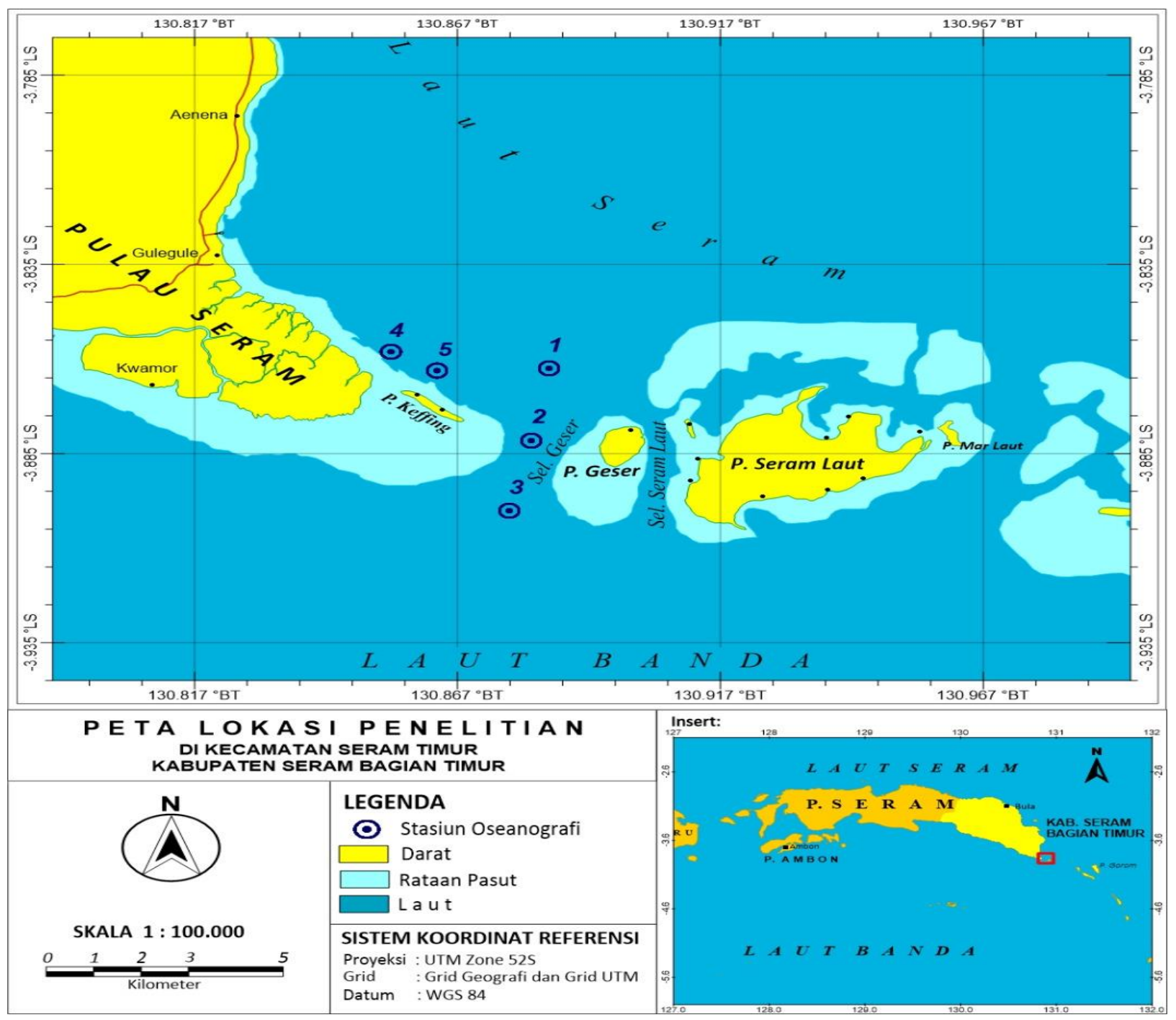

Gambar 1. Lokasi pengambilan sampel zooplankton di Pesisir Keffing, 2017. 
ditempati oleh Stasiun 1 dan 2 dengan nilai 16 jenis, dan paling rendah Stasiun 5 dengan total komposisi zooplankton sebanyak 12 jenis. Komposisi jenis zooplankton di perairan pesisir Keffing lebih sedikit bila dibandingkan dengan komposisi jenis di pesisir Teluk kao, Halmahera yang mencapai 31 jenis (Wiadnyana, 1997); Komposisi jenis di pesisir
Pulau Nusalaut, Maluku yang mencapai 37 jenis (Mulyadi, 2011); dan di pesisir Pulau Panjang mencapai 25 jenis (Sari $d k k, 2014$ ).

Copepoda mendominasi perairan pesisir Keffing dengan 13 jenis $(46,43 \%$ dari total komposisi zooplankton). Beberapa jenis copepoda yang teridentifikasi di semua

Tabel 1. Komposisi zooplankton di Pesisir Pulau Keffing, November 2017

\begin{tabular}{|c|c|c|c|c|c|c|c|}
\hline No & & Kelompok & STI & ST2 & ST3 & ST4 & ST5 \\
\hline 1 & Holoplankton & Acartia sp & - & - & - & - & - \\
\hline 2 & & Pontella sp & - & - & - & $\bullet$ & - \\
\hline 3 & & Temora sp & • & • & • & - & - \\
\hline 4 & & Tortanus sp & • & • & • & • & • \\
\hline 5 & & Euchaeta sp & - & • & - & - & - \\
\hline 6 & & Acrocalanus sp & - & • & - & $\bullet$ & • \\
\hline 7 & & Eucalanus sp & • & • & • & • & • \\
\hline 8 & & Copilia sp & - & - & - & - & • \\
\hline 9 & & Oncaea sp & - & • & • & • & • \\
\hline 10 & & Corycaeus sp & • & • & • & • & • \\
\hline 11 & & Macrosetella sp & - & • & - & • & • \\
\hline 12 & & Juvenil Copepoda & - & - & • & • & - \\
\hline 13 & & Telur Copepoda & - & - & - & - & - \\
\hline 14 & & Pyrocypris sp & - & - & - & - & - \\
\hline 15 & & Euchonchaecia sp & - & - & - & - & - \\
\hline 16 & & Lucifer & - & - & - & - & • \\
\hline 17 & & Acetes & - & - & - & - & - \\
\hline 18 & & Mysis & - & - & - & - & - \\
\hline 19 & & Pseudeuphausia & - & - & - & - & - \\
\hline 20 & & Sagita enflata & - & - & • & - & • \\
\hline 21 & & Thaliacea & - & - & • & - & - \\
\hline 22 & & Larvacea & • & • & • & - & • \\
\hline 23 & & Siphonopora & - & - & - & • & - \\
\hline 24 & & Medusae & - & • & - & - & $\bullet$ \\
\hline 25 & Meroplankton & Larva Cirripedia & - & - & - & - & - \\
\hline 26 & & Larva Echinodermata & - & - & - & - & - \\
\hline 27 & & Larva Gastropoda & • & • & • & - & - \\
\hline 28 & & Telur Ikan & • & - & - & $\cdot$ & - \\
\hline \multicolumn{3}{|c|}{ JUMLAH } & 16 & 16 & 14 & 18 & 12 \\
\hline
\end{tabular}


stasiun adalah Tortanus sp, Eucalanus sp, Oncaea sp, dan Corycaeus sp. Hal ini sejalan dengan Mulyadi (2004) yang menyatakan bahwa copepoda yang umum dijumpai di perairan Indonesia ada 99 jenis, beberapa diantaranya adalah Eucalanus, Labidocera, Acartia dan Acrocalanus. Jenis-jenis copepoda yang teridentifikasi di Pulau Keffing merupakan copepoda yang menghuni perairan pesisir (tipe estuarine dan tipe neritik).

Meroplankton di pesisir Keffing terdiri dari empat jenis yaitu larva Cirripedia, larva Echinodermata, larva gastropoda dan telur ikan. Kondisi ini lebih sedikit jika dikomparasi dengan komposisi jenis meroplankton di pesisir Teluk Ambon yang mencapai 13 jenis (Mulyadi, 2013). Sedikitnya komposisi jenis meroplankton di pesisir Pulau Keffing pada MP II diduga berkaitan dengan tidak sedang berlangsungnya musim pemijahan atau bukan puncak waktu pemijahan dari biota laut tertentu seperti bivalvia, moluska, gastropoda, polychaeta dan echinodermata. Kelimpahan zooplankton di pesisir Pulau Keffing selama musim peralihan II (MP II) berfluktuasi antar stasiun pengamatan. Kelimpahan zooplankton secara lebih detail tersaji pada Tabel 2.

Berdasarkan Tabel 2, terlihat bahwa kelimpahan zooplankton berkisar antara 351$1190 \mathrm{ind} / \mathrm{m}^{3}$. Nilai kisaran ini lebih kecil bila dibandingkan dengan kelimpahan zooplankton di Teluk Kao, Halmahera yang mencapai 586-8246 ind $/ \mathrm{m}^{3}$ (Wiadnyana, 1997); dan kelimpahan total zooplankton di Pesisir Morella pada musim timur yang mencapai 752-1050 ind $/ \mathrm{m}^{3}$ (Mulyadi \& Wahab, 2015). Rendahnya kelimpahan zooplankton di pesisir Pulau Keffing pada MP II diduga terkait dengan ketersediaan pakan alaminya, dalam hal ini kelimpahan fitoplankton. Pada beberapa perairan pesisir yang terkoneksi secara langsung dengan Laut Banda, dikenal dengan adanya fenomena upwelling (naiknya massa air yang kaya nutrisi, subur) pada musim timur di Laut Banda yang terjadi pada bulan Juni-Agustus (Wyrtki, 1961; Gordon \& Fine, 1996; Pranowo, 2012;) sehingga meningkatkan kelimpahan fitoplankton di Laut Banda dan perairan di sekitarnya (Sediadi, 2004). Kondisi perairan yang subur selama musim timur akan diikuti dengan melimpahnya fitoplankton dan zooplankton sebagai konsumen tingkat pertama. Namun, ketika ketersediaan unsur hara (kesuburan perairan) yang semakin menipis pada MP II (September-November), maka kelimpahan plankton juga akan menurun.

Copepoda muncul sebagai kelompok yang dominan dengan nilai kelimpahan berkisar antara 251-965 ind $/ \mathrm{m}^{3}$ (47-81\%), diikuti oleh appendicularian dengan nilai berkisar antara $13-163$ ind $/ \mathrm{m}^{3}$ (2-23\%), dan meroplankton dengan kisaran nilai kelimpahan 0-75 ind $/ \mathrm{m}^{3}$ (0-10\%) sesuai Tabel 2. Hal ini sesuai dengan beberapa kajian yang menyebutkan bahwa Copepoda mendominasi dari total kelimpahan zooplankton (Pinca \& Dallot,1997; Rakhesh et al, 2008; dan Eloire et al., 2010; Goncalves et al., 2015) dan menegaskan bahwa Copepoda merupakan komponen penting penyusun zooplankton di suatu perairan.

Beberapa jenis Copepoda yang mempunyai nilai kelimpahan rata-rata tertinggi adalah Oncaea sp, Eucalanus sp dan Corycaeus sp dengan nilai kelimpahan rata-rata secara berurutan sebesar $163 \pm 137.53 \mathrm{ind} / \mathrm{m}^{3}, 115 \pm 70.54 \mathrm{ind} / \mathrm{m}^{3}$ dan $65 \pm 46.37 \mathrm{ind} / \mathrm{m}^{3}$. Tingginya nilai kelimpahan dari jenis copepoda tersebut terkait dengan jenis copepoda pesisir dan estuarine yang bersifat euryhaline yaitu mempunyai rentang kisaran toleransi yang luas terhaap salinitas (Mulyadi, 2004). Dengan kemampuan beradaptasi yang luas terhadap kondisi oseanografi di peisisir Pulau Keffing, terutama faktor salinitas, maka copepoda tersebut mempunyai pertumbuhan dengan baik.

Appendicularian berada di urutan kedua setelah copepoda. Teridentifikasi ada dua jenis yaitu Thalia dan Larvacea. Namun dari kedua jenis tersebut, Larvacea muncul dalam jumlah yang melimpah dengan kisaran mencapai $13-138 \mathrm{ind} / \mathrm{m}^{3}$ dan ratarata sebesar $\left(88 \pm 53.89\right.$ ind $\left./ \mathrm{m}^{3}\right)$. Kondisi berbeda untuk Thalia yang hanya muncul di Stasiun 3 dengan kelimpahan $25 \mathrm{ind} / \mathrm{m}^{3}$. Hal ini analog dengan kajian Cornils et al., (2010) yang menjelaskan bahwa appendicularian menempati urutan kedua setelah copepoda di perairan pesisir Pulau Spermonde, Sulawesi. Lebih lanjut (Nakamura, 1997) memaparkan 
bahwa appendicularian Oikopleura berperan penting dalam produktivitas sekunder di Pesisir Seto Island, Jepang selama musim panas; dimana laju produktivitas sekundernya dipengaruhi oleh ledakan populasi (blooming) dari pikoplankton spesies penyebab red tide yaitu Gymnodinium mikimotoi (Nakamura et al., 1997).

Meroplankton menempati urutan ketiga dalam hal kelimpahan di pesisir Pulau Keffing selama MP II (Tabel 2). Keberadaan meroplankton di suatu perairan dapat mencirikan bahwa daerah tersebut merupakan daerah asuhan (nursery ground), atau daerah untuk bertelur (nesting area) bagi beberapa biota laut seperti bivalvia, echinodermata, gastropoda maupun larva polychaeta. Hal ini didukung dengan kajian P2LD LIPI \& PEMKAB SBT (2017) yang menjelaskan bahwa di daerah pesisir Keffing kondisi ekosistem terumbu karang dan padang lamunnya masih sangat bagus sehingga biota asosiasi dapat tumbuh dengan baik. Nilai kelimpahan meroplankton (larva-larva planktonis biota laut tertentu) selama MP II berkisar antara $0-13$ ind $/ \mathrm{m} 3$ (larva cirripedia), $\quad 0-25$ ind $/ \mathrm{m} 3$ (larva

Tabel 2. Kelimpahan zooplankton untuk masing-masing jenis (ind/m³), Keffing 2017

\begin{tabular}{|c|c|c|c|c|c|c|c|}
\hline No & & Kelompok & STI & ST2 & ST3 & ST4 & ST5 \\
\hline 1 & \multirow[t]{24}{*}{ Holoplankton } & Acartia sp & 38 & 25 & 13 & 13 & 0 \\
\hline 2 & & Pontella sp & 0 & 0 & 0 & 13 & 0 \\
\hline 3 & & Temora sp & 13 & 25 & 13 & 0 & 0 \\
\hline 4 & & Tortunus sp & 50 & 75 & 38 & 25 & 13 \\
\hline 5 & & Euchaeta sp & 0 & 13 & 0 & 0 & 0 \\
\hline 6 & & Acrocalanus sp & 38 & 63 & 0 & 75 & 13 \\
\hline 7 & & Eucalanus sp & 100 & 238 & 75 & 100 & 63 \\
\hline 8 & & Copilia sp & 0 & 0 & 0 & 0 & 13 \\
\hline 9 & & Oncaea sp & 238 & 363 & 125 & 50 & 38 \\
\hline 10 & & Corycaeus sp & 63 & 138 & 25 & 25 & 75 \\
\hline 11 & & Macrosetella sp & 25 & 25 & 0 & 25 & 38 \\
\hline 12 & & Juvenil Copepoda & 0 & 0 & 13 & 13 & 0 \\
\hline 13 & & Telur Copepoda & 0 & 0 & 88 & 0 & 0 \\
\hline 14 & & Pyrocypris sp & 13 & 13 & 0 & 0 & 0 \\
\hline 15 & & Euchonchaecia sp & 50 & 38 & 13 & 25 & 13 \\
\hline 16 & & Lucifer & 0 & 0 & 0 & 25 & 13 \\
\hline 17 & & Acetes & 13 & 0 & 0 & 0 & 0 \\
\hline 18 & & Mysis & 0 & 0 & 13 & 0 & 0 \\
\hline 19 & & Pseudeuphausia & 13 & 0 & 0 & 0 & 0 \\
\hline 20 & & Sagita enflata & 13 & 0 & 50 & 75 & 13 \\
\hline 21 & & Thaliacea & 0 & 0 & 25 & 0 & 0 \\
\hline 22 & & Larvacea & 13 & 113 & 138 & 125 & 50 \\
\hline 23 & & Siphonopora & 0 & 0 & 0 & 38 & 0 \\
\hline 24 & & Medusae & 0 & 13 & 0 & 25 & 13 \\
\hline 25 & \multirow[t]{4}{*}{ meroplankton } & Larva Cirripedia & 0 & 0 & 0 & 13 & 0 \\
\hline 26 & & Larva Echinodermata & 0 & 25 & 0 & 0 & 0 \\
\hline 27 & & Larva Gastropoda & 38 & 25 & 25 & 50 & 0 \\
\hline 28 & & Telur Ikan & 13 & 0 & 0 & 13 & 0 \\
\hline \multicolumn{3}{|c|}{ JUMLAH } & 727 & 1190 & 652 & 727 & 351 \\
\hline
\end{tabular}


echinodermata), $0-50$ ind $/ \mathrm{m} 3$ (larva gastropoda) dan 0-13 ind/m3 untuk telur ikan (Tabel 2), hal ini mengindikasikan bahwa pada MP II bukan merupakan puncak pemijahan dari biota laut tersebut.

\section{Kondisi Oseanografis}

Kondisi oseanografis perairan pesisir Pulau Keffing pada MP II berdasarkan data profil CTD di 5 stasiun pada November 2017 (Gambar 2a) mempunyai kisaran suhu 28,0630,14 ${ }^{\circ} \mathrm{C}$. Kisaran nilai suhu pada musim MP ॥ lebih lebar dari musim barat dan MP I. Suwartana (1985) menjabarkan bahwa pada musim barat nilai kisaran suhu 28,61-29,31 ${ }^{\circ} \mathrm{C}$ dan Hadikusumah (2010) menjelaskan bahwa pada musim peralihan I nilai kisaran suhu 28,56- $29,24^{\circ} \mathrm{C}$. Kisaran nilai suhu pada musim timur lebih rendah dibandingkan dengan musim-musim yang lain yaitu berkisar antara 26.8 - 27.5॰ C (llahude \& Nontji, 1999) dan antara $27.17-28.8^{\circ} \mathrm{C}$ (Wijaya dkk., 2011) dan antara $25-28^{\circ} \mathrm{C}$ (Kusmanto dan Surinati, 2016).
Profil vertikal suhu (Gambar 2a) menunjukkan sebaran tegak suhu stasiun 1 berada pada kisaran suhu ini, berbeda dengan empat stasiun lainnya yang sangat homogen dengan kisaran suhu sempit $(28,91$ - 29,86 ${ }^{\circ} \mathrm{C}$ ), dipengaruhi oleh proses pengadukan arus pasut di perairan pantai dan di Selat Geser. Sebaran melintang suhu (Gambar 3a dan 4a) menunjukkan perairan dekat pantai (stasiun 4 dan 5) dan perairan selat (stasiun 2 dan 3) mempunyai sebaran suhu lebih homogen dari stasiun 1 pada kedalaman yang sama.Suhu dan salinitas merupakan parameter fisika oseanografis yang penting bagi biota laut termasuk zooplankton. Kedua parameter ini baik suhu dan salinitas air dapat mempengaruhi distribusi dan kelimpahan zooplankton (Queiroga et al. 2005; Shimode et al., 2006; Marques et al., 2008; Brugnano et al., 2009)

Profil vertikal salinitas perairan pesisir Pulau Keffing pada musim peralihan II (Gambar 2b) mempunyai kisaran antara
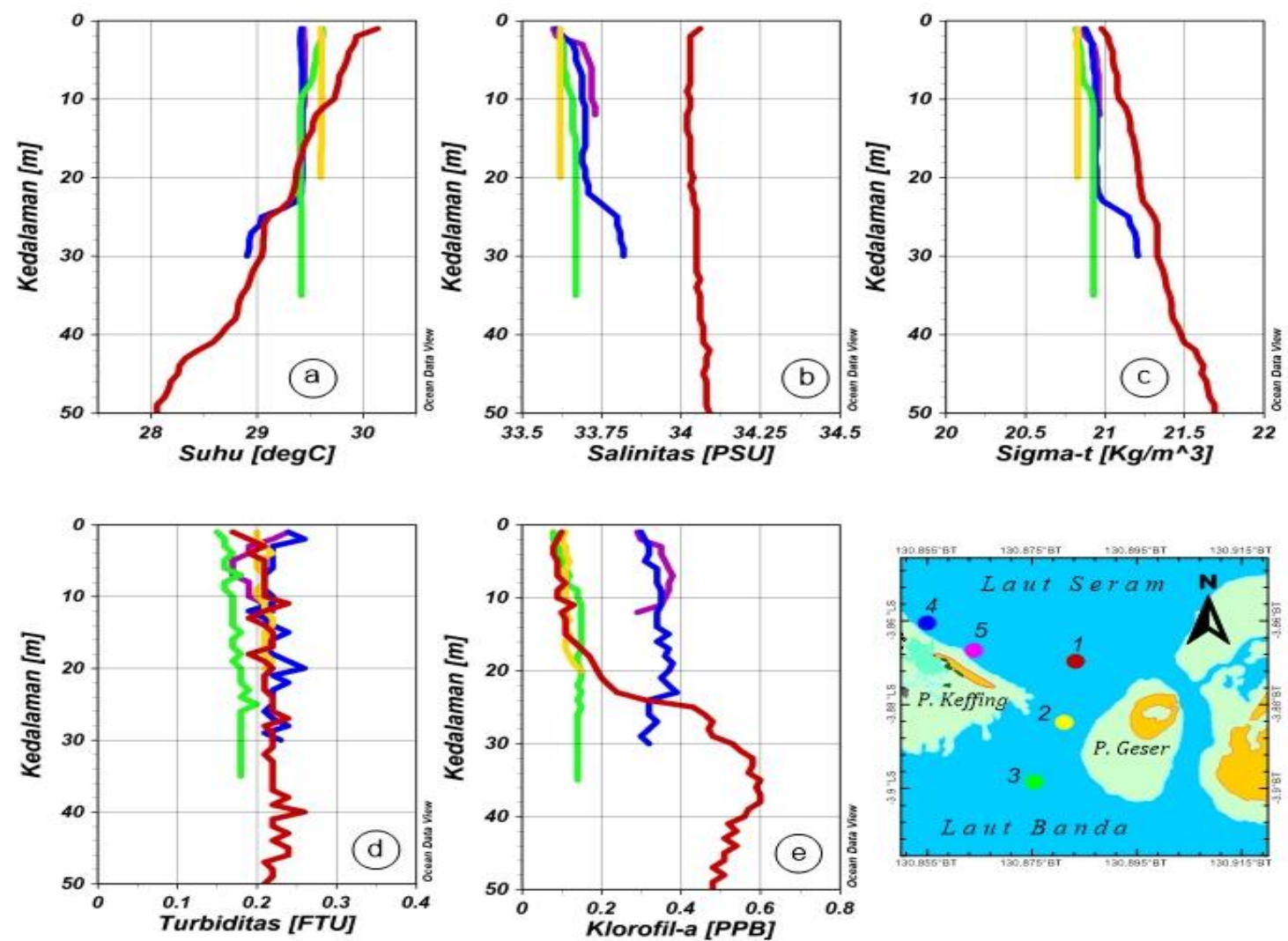

Gambar 2. Sebaran melintang suhu, salinitas dan klorofil-a di Selat Geser. 
33,60 - 34,09 PSU, dengan sebaran menegak salinitas hampir homogen pada tiap stasiun, namun konsentrasi salinitas pada stasiun 1 lebih tinggi $(34,02-34,09$ PSU), dari empat stasiun lainnya (33,60 - 33,83 PSU). Sebaran melintang salinitas (Gambar 3b dan 4b) menunjukkan front oleh perbedaan salinitas antara stasiun 1 dengan stasiun 2, 3, 4 dan 5, dan ini mengindikasikan pola sirkulasi air pasang keluar dari Selat Geser ke utara cenderung membelok ke arah kiri oleh pengaruh coriolis pada kecepatan arus maksimum di Selat Geser. Proses ini akan mempengaruhi distribusi salinitas yang dapat berpengaruh terhadap pola distribusi organisme laut yang menghuni lapisan eufotik di perairan pesisir Pulau Keffing. Hal ini sejalan dengan kajian Queiroga et al., 2005 yang menjabarkan bahwa salinitas perairan berpengaruh terhadap distribusi zooplankton.
Densitas perairan pesisir Pulau Keffing yang ditentukan oleh suhu, salinitas dan tekanan massa air pada musim peralihan II, mempunyai kisaran sigma- $\dagger$ antara 20,82 $21,69 \mathrm{~kg} / \mathrm{m}^{3}$. Profil vertikal sigma- $\dagger$ (Gambar 2c) menunjukkan pengaruh suhu lebih dominan terhadap disribusi vertikal massa air, dimana penurunan suhu terhadap kedalaman meningkatkan sigma-t. Sebaran melintang sigma- $t$ (Gambar 3c dan 4c) menunjukkan massa air berdensitas tinggi berada di stasiun 1 pada sigma-t rerata 21,31 $\mathrm{Kg} / \mathrm{m}^{3}$, dan massa air berdensitas rendah berada di stasiun 2,3 , 4, dan 5 dengan sigma- $\dagger$ rerata $20,92 \mathrm{Kg} / \mathrm{m}^{3}$. Perbedaan densitas ini akan menyebabkan perbedaan sirkulasi pada air pasang dan surut, dimana pola sirkulasi arus pasang seperti yang telah diutarakan, sedangkan pada sirkulasi arus surut, massa air stasiun 1 yang mempunyai
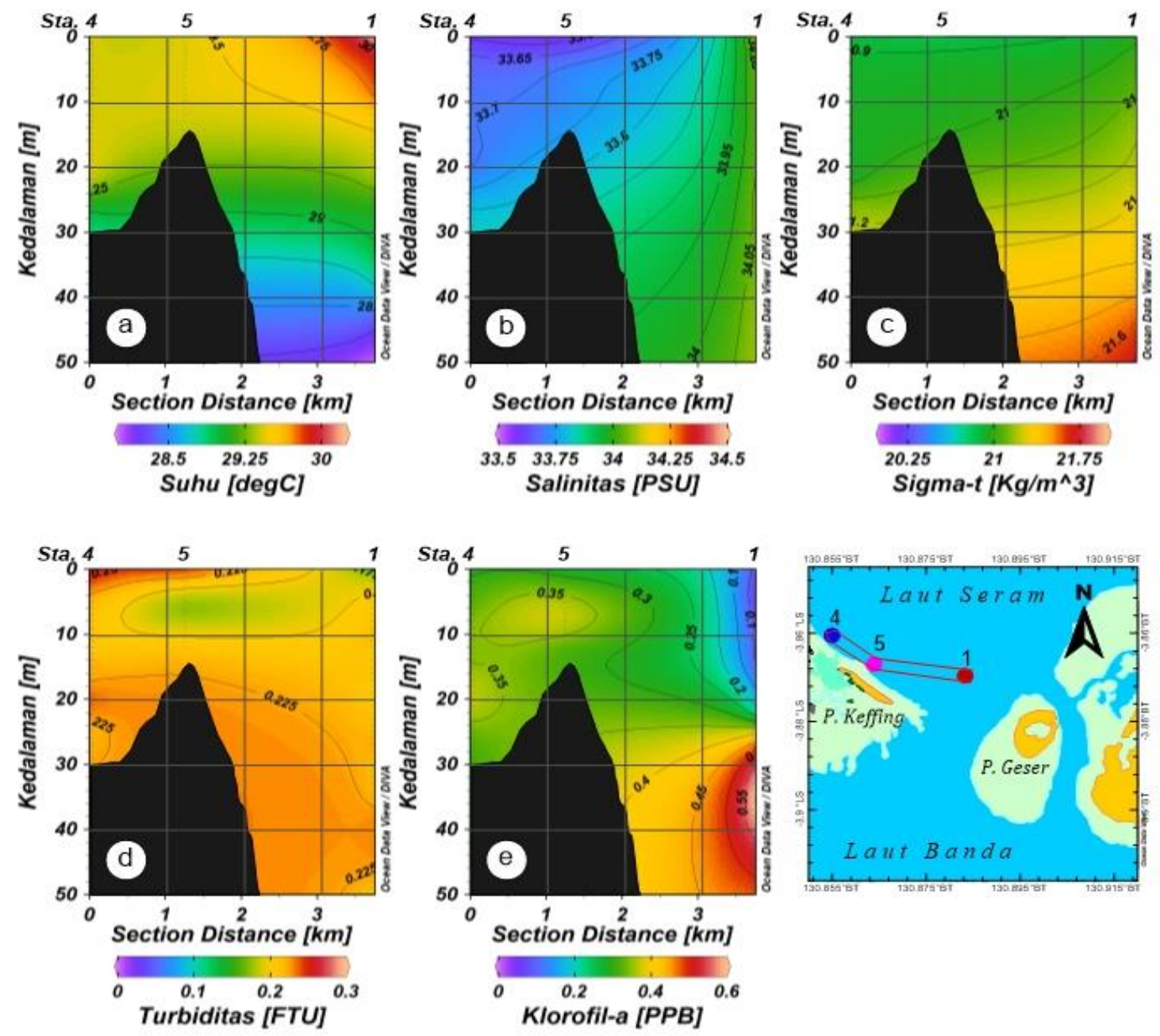

Gambar 3. Sebaran melintang suhu, salinitas dan klorofil-a di Selat Geser. 
massa lebih besar akan mendominasi Selat Geser karena mempunyai momentum gaya dan energi kinetik lebih besar dari massa air stasiun 4 dan 5. Besaran nilai densitas perairan dipengaruhi oleh faktor suhu, salinitas dan tekanan/pressure (Millero, 2010).

Kekeruhan yang disebabkan oleh partikel tersuspensi di perairan pesisir Pulau Keffing pada musim peralihan II yang ditentukan oleh pengukuran turbiditas. Profil vertikal turbiditas (Gambar 2d) mempunyai berkisaran antara $0,15-0,26$ FTU, rerata 0,21 FTU. Sebaran menegak turbiditas (Gambar 3d dan 4d) menunjukkan turbiditas yang tinggi berada di permukaan stasiun 4 (0,22 - 0,26 FTU) dan turbiditas rendah berada di stasiun 3
$(0,15-0,17$ FTU) dan di permukaan stasiun 1 . Perbedaan nilai turbiditas pada ke lima stasiun ini mengindikasikan adanya pengaruh proses pantai dan pengaruh kepadatan mikroorganisme di sekitar ekosistem terumbu karang lebih tinggi dari stasiun 1, 2 dan 3 yang berjauhan dari pantai. Kekeruhan (turbidity) diduga menurunkan keanekaragaman plankton, adanya indikasi dominasi dari plankton tertentu dan berkorelasi negatif terhadap kondisi larva ikan. Hal ini sesuai dengan Pereira et al., (2005) yang menjabarkan bahwa tingginya nilai kekeruhan perpengaruh terhadap menurunnya diversitas plankton dan munculnya indikasi dominasi dari spesies tertentu yang mampu beradaptasi pada
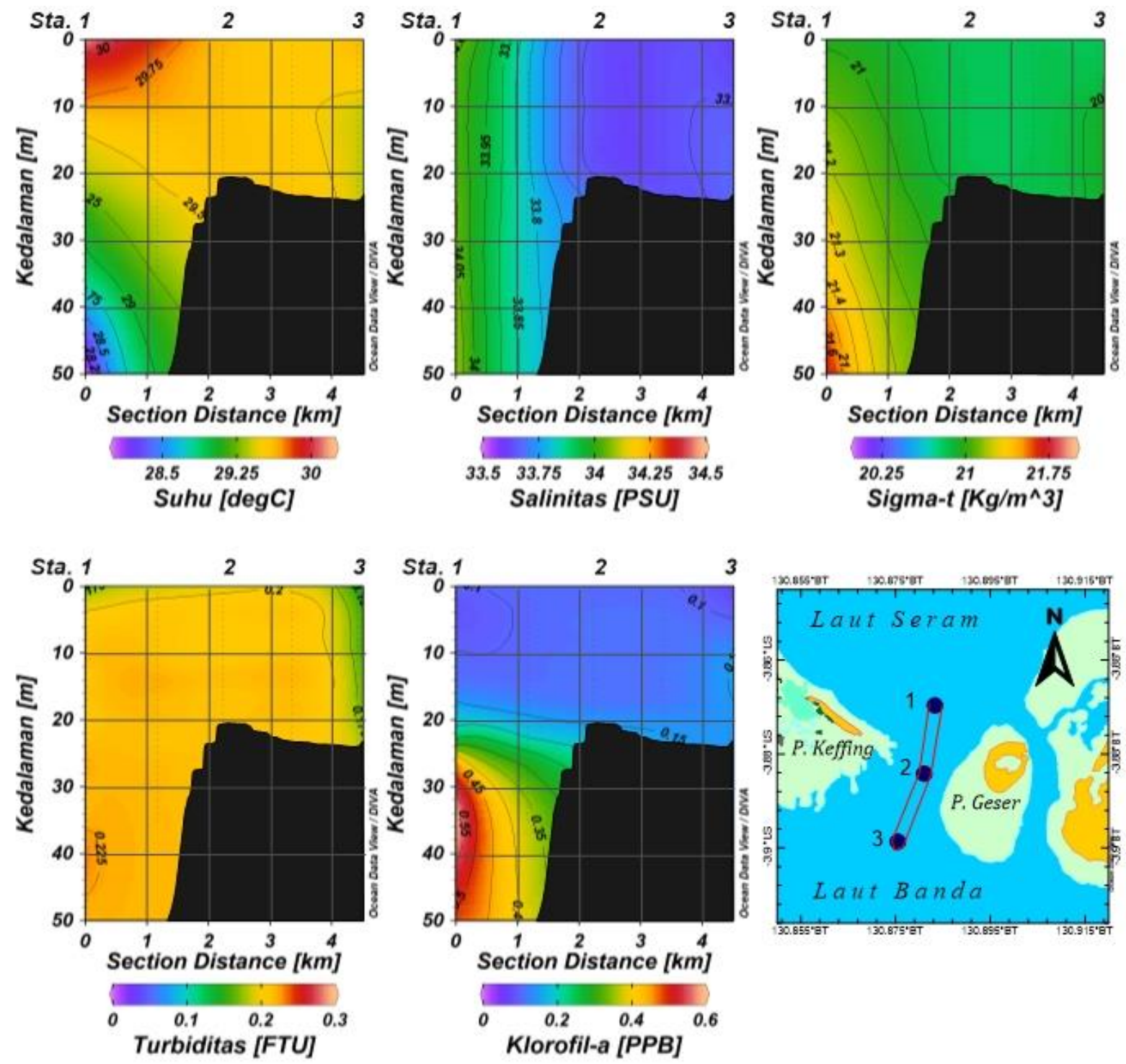

Gambar 4. Sebaran melintang suhu, salinitas dan klorofil-a di utara P. Keffing. 
kondisi perairan yang kekeruhannya tinggi. Lebih lanjut Salonen et al., (2009)menjelaskan bahwa kondisi larva ikan Pike (Esox lucius) menurun seiring dengan meningkatnya nilai kekeruhan.

Kesuburan perairan pesisir Pulau Keffing pada Musim peralihan II digambarkan oleh profil vertikal klorofil-a (Gambar 2e). Konsentrasi klorofil-a hasil pengukuran berkisar antara 0,08 - 0,60 PPB, rerata 0,23 PPB, dengan perbedaan pola distribusi yaitu, pada stasiun 1 distribusi klorofil-a meningkat dari kedalaman 15 meter menuju nilai maksimum 0,60 PPB pada kedalamaan 67 38 meter, sedangkan stasiun 2 dan 3 di selat dan stasiun 4 dan 5 di utara Pulau Keffing mempunyai pola sebaran menegak hampir homogen, namun di stasiun 2 dan 3 terlihat lebih rendah dengan nilai klorofil-a rerata 0,013 PPB, dan di stasiun 4 dan 5 yang lebih tinggi mempunyai nilai klorofill-a rerata 0,34 PPB. Perbedaan pada ke tiga lokasi ini menunjukkan adanya pengaruh arus terhadap pengadukan kolom air serta pola distribusi klorofil-a. Korelasi antara klorofil-a dengan total zooplankton bernilai positif (Mulyadi, 2011), begitu juga dengan copepoda (Kang \& Ohman, 2014). Namun studi yang lain menyebutkan bahwa korelasi antara klorofil-a dengan zooplankton tidak signifikan (Kurt \& Polat, 2015).

\section{Analisis PCA Parameter Fisika Oseanografis Perairan}

Parameter oseanografis perairan yang meliputi suhu, salinitas, sigma-t, turbidity, klorofil-a di analisa dengan pendekatan PCA (Principal component analysis). Nilai eigenvalues dan factor score tersaji pada Tabel 3, sedangkan analisis biplot tersaji pada Gambar 5.

Berdasarkan analisa PCA, nilai F1 sebesar $99.99 \%$ dari total variasi. Parameter suhu, salinitas, dan sigma-t (densitas) mempunyai nilai positif sedangkan klorofil-a dan turbiditas mempunyai nilai negatif. Suhu perairan mempunyai peranan penting dalam kehidupan zooplankton. Pada kisaran suhu tertentu zooplankton mampu tumbuh dengan baik. Hal ini sejalan dengan Brugnano et al., (2009) bahwa suhu perairan dapat mempengaruhi fekunditas, pertumbuhan dan survival rate dari zooplankton jenis Pseudocyclops xiphophorus. Begitu juga dengan salinitas perairan yang berkontribusi terhadap distribusi dan kelimpahan zooplankton (Shimode et al., 2006; Marques et al., 2008). Densitas perairan (kombinasi dengan suhu dan salinitas) berkontribusi terhadap sebaran (dispersal) dari larva planktonis biota laut (Marsh et al., 2001). Lebih lanjut, densitas perairan dapat mempengaruhi proses kalsifikasi cangkang plankton foraminifera (Zarkogiannis et al., 2019).

Parameter klorofil-a fluorescent dan turbidity mempunyai nilai negatif. Klorofil-a merupakan pigmen yang dihasilkan oleh fitoplankton sehingga dapat digunakan sebagai indikator tingkat kesuburan perairan. Namun pada kondisi blooming fitoplankton beracun (harmful algal blooms-HABs), tingginya klorofil-a dapat berkorelasi negatif dengan zooplankton. Pada saat terjadi blooming fitoplankton beracun, nilai dari klorofil-a di perairan tinggi tetapi karena yang melimpah adalah fitoplankton beracun maka akan berpengaruh negatif terhadap pertumbuhan zooplankton. Hal ini sejalan dengan (Turner et al., 2012) yang menjelaskan bahwa Copepoda Calanus helgolandicus mengalami penurunan produksi telur (eggs production) dan kegagalan telur copepoda untuk menetas (hatching eggs) setelah terpapar fitoplankton beracun (HABs) jenis Karenia brevis.

Turbiditas (bersama dengan klorofil-a) mempunyai nilai yang hampir sama yaitu 2,626 dan -2,618 (Tabel 3) dan tampak saling berhimpit pada biplot model (Gambar 5). Turbiditas merupakan sifat optik perairan yang menggambarkan adanya bahan organik dan anorganik di suatu perairan. Turbiditas dapat berpengaruh negatif terhadap kehidupan zooplankton yaitu menurunkan laju produksi telur sebagai akibat dari terganggunya proses fotosintesis pada perairan dengan nilai turbiditas tinggi. Hal ini sejalan dengan Burdloff et al., (2000) yang menjelaskan bahwa rendahnya laju produksi telur copepoda jenis Eurytemora affinis dipengaruhi oleh kondisi perairan yang turbiditasnya tinggi. Lebih lanjut dijelaskan bahwa Kombinasi antara turbiditas perairan yang tinggi menyebabkan rendahnya laju 
Tabel 3. Nilai eigenvalues dan factor score parameter oseanografis perairan.

\begin{tabular}{lrr}
\hline \multicolumn{1}{c}{ Observation } & Fl & \multicolumn{2}{c}{ F2 } \\
\hline Suhu & 1.960 & -0.032 \\
Salinitas & 2.644 & 0.016 \\
Sigma- $\dagger$ & 0.641 & 0.019 \\
Klorofil-a & -2.618 & 0.004 \\
Turbiditas & -2.626 & -0.007 \\
Eigenvalues & 99.99 & 100 \\
\hline
\end{tabular}

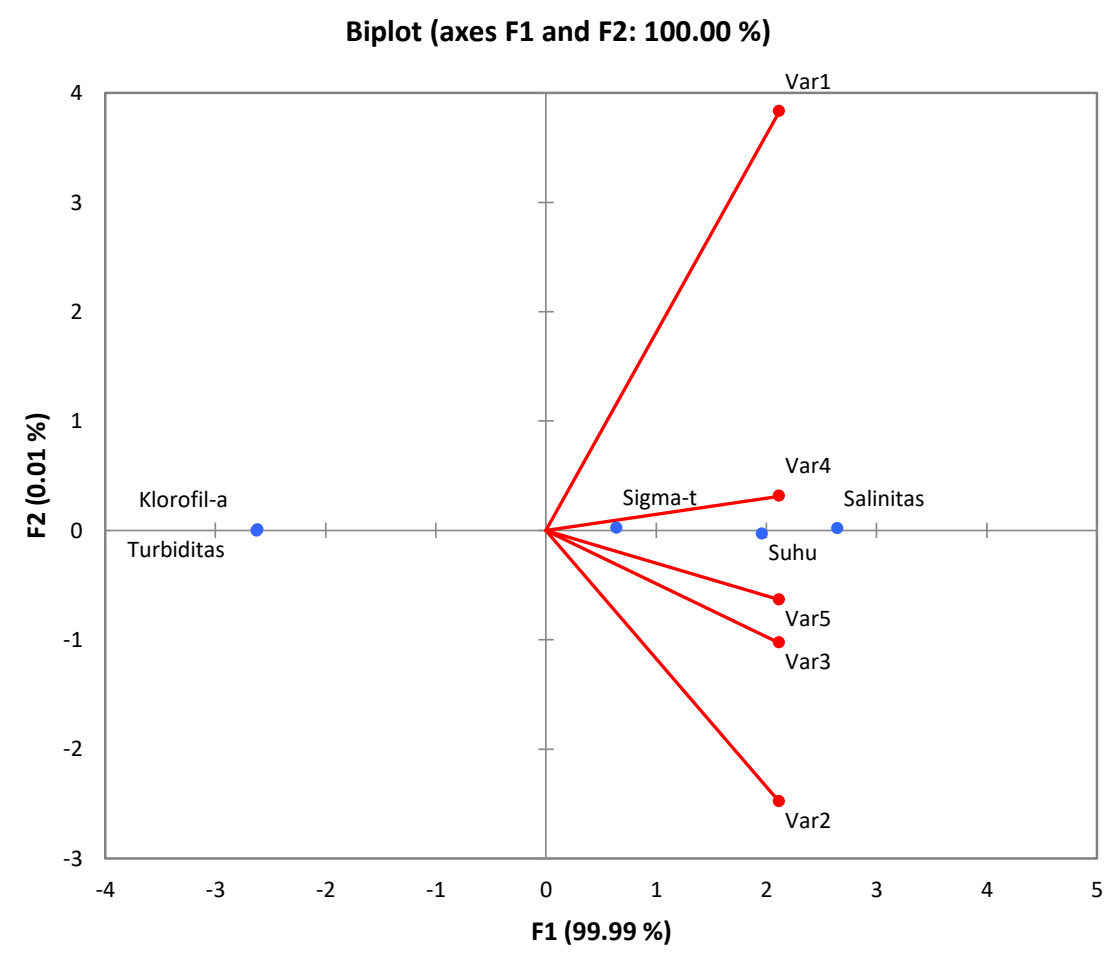

Gambar 5. Biplot (F1 dan F2) analisis PCA parameter oseanografis di Pulau Keffing.

fotosintesa dan rendahnya fitoplankton karena faktor cahaya yang terbatas sehingga berpengaruh terhadap rendahnya laju produksi telur copepoda.

\section{KESIMPULAN}

Biodiversitas zooplankton di perairan pesisir Pulau Keffing selama musim peralihan II sebanyak 28 spesies. Copepoda menjadi kelompok yang dominan dengan jenis yang melimpah adalah Oncaea sp, Eucalanus sp dan Corycaeus sp. Copepoda menjadi komponen penting penyusun zooplankton di peisisir Pulau Keffing. Copepoda merupakan makanan utama bagi ikan-ikan pelagis kecil yang termasuk pemakan plankton (planktivorous fish). Implikasi penelitian ini dapat dimanfaatkan sebagai landasan ilmiah bagi stakeholders terkait dalam membuat strategi pengelolaan sumberdaya perikanan pelagis kecil di pesisir Pulau Keffing.

\section{DAFTAR PUSTAKA}

Bureau of technical supervision of the P.R of China. 1992. The Specification for Oceanographic Survey, Oceanographic 
Survey Data Processing (GB/T 12763.7-91). Standards press of China. P. 68-70.

BPS Kab Seram Bagian Timur. Kecamatan Seram Timur Angka 2018.35 hal.

Brugnano, C., Guglielmo, L., lanora, A. \& Zagami, G. 2009. Temperature effects on fecundity, development and survival of the benthopelagic calanoid copepod Pseudocyclops xiphophorus. Marine Biology, 156:331-340.

Burdloff, D., Gasparini, S., Sautour, B., Etcheber, H. \& Castel, J. 2000. Is the copepod egg production in a highly turbid estuary (the Gironde, France) a funtion of the biochemical composition of seston? Aquatic Ecology 34:165-175.

Cornils, A., Schulz, J., Schmitt, P., Lanuru, M., Richter, C. \& Schnack-Schiel, S.B. 2010. Mesozooplankton distribution in the Spermonde Archipelago (Indonesia, Sulawesi) with special refference to the calanoida (copepoda). Deep-Sea Research II (57):2076-2088.

Eloire, D., Somerfield, P.J., Conway, D.V.P., Halsband-Lenk, C., Harris, R., \& Bonnet, D., 2010. Temporal variability and community composition of zooplankton at station L4 in the Western Channel: 20 years of sampling. Journal of Plankton Research 32(5):657-679.

Goncalves, D.A., Marques, S.C., Primo, A.L., Martinho, F., Bordalo, M.D.B. \& Pardal, M.A., 2015. Mesozooplankton biomass and copepod estimated production in a temperate estuary (Mondego estuary): effects of processes operating at different timescales. Zoological Studies 54-57. doi : 10.1186/s40555-015-0135-6.

Gordon, A.L. \& Fine, R.A. 1996. Pathways of water between the Pacific and Indian Oceans in Indonesian seas. Nature, 379 (6561):146.

Hadikusumah. 2010. Massa air subtropical di perairan Hamahera. Jurnal Ilmu dan Teknologi Kelautan Tropis, 2(2):92-108.

Hutabarat, S. \& Evans, S.M. 1986. Kunci Identifikasi Zooplankton. Jakarta UI Press.

Illahude, A.G. \& Nontji, A.1999. Oseanografi Indonesia dan perubahan iklim global (La Nina dan El Nino).Lembaga IImu Pengetahuan Indonesia. Makalah dipresentasikan dalam Lokakarya Kita dan perubahan iklim global: kasus elnino dan la nina di AlPI, Jakarta, 18-19 Mei 2009.13 hal.

Kang, Y.S. \& Ohman, M.D. Comparison of long-term trends of zooplankton from two marine ecosystems across the North Pacific: Norththeastern Asian marginal sea and southern California current system. Calcofi Report 55.

Kurt, T.T. \& Polat, S. 2015. Zooplankton abundance, biomass, and size structure in the coastal waters of the northeastern Mediterranian Sea. Turk. J. Zool. 39:378387.

Kusmanto, E. \& Surinati, D., 2016. Stratifikasi Massa Air di Teluk Lasolo, Sulawesi Tenggara. Oseanologi dan Limnologi dan di Indonesia, 1 (2):17-29.

Marsh, AG., Mullineaux, L.S., Young, C.M. \& Manahan, D.T. 2001. Larval dispersal potential of the tubeworm Riftia pachyptila at deep-sea hydrothermal vents. Nature, $411: 77-80$.

Marques, S.C., Azeiteiro, U.M., Leandro, S.M., Queiroga, H., Primo, A.L., Martinho, F., Viegas I., \& Pardal, M.A.. 2008. Predicting zooplankton response to environmental changes in a temperate estuarine ecosystem. Marine Biology, 155:531-541.

Millero, F.J. 2010. History of the equation of state of seawater. Oceanography 23(3).

Mulyadi, 2004. Calanoid copepods in Indonesian waters. Nagano Natural Environmental Foundation. Published by Research Centre for Biology, Indonesian Institute of Sciences, Bogor, Indonesia. $195 \mathrm{pp}$.

Mulyadi, H.A. 2011. Keterkaitan antara zooplankton predominan dengan kandungan klorofil-a di sekitar perairan pesisir Pulau Nusalaut, Maluku. Oseanologi dan Limnologi dan di Indonesia, 37(3):415-433.

Mulyadi, 2013. Urgensi pengelolaan kawasan pesisir Teluk Ambon ditinjau dari aspek sumberdaya meroplankton. Prosiding Seminar Nasional Pengelolaan Sumberdaya Alam dan Lingkungan 2013. Program Studi Lingkungan program Pasca Sarjana Universitas Diponegoro. 342-348.

Mulyadi, H.A \& Radjab, A.W.. 2015. Dinamika spasial kelimpahan zooplankton pada musim timur di perairan pesisir Morella, 
Maluku Tengah. Jurnal Ilmu dan Teknologi Kelautan Tropis, 7(1):109-122.

Nakamura, Y. 1997. Blooms of tunicates Oikopleura spp. And Dolioletta gegenbauri in the seto Island Sea, Japan, during Summer. Hydrobiologia, 385:183192.

Nakamura, Y., Suzuki., K., Suzuki S., \& Hiromi, J. 1997. Production of Oikopleura dioica (Appendicularia) following picoplankton "blooms" in a euthropic coastal area. Journal of Plankton Research, 19(1):113124.

Omori, M. \& Ikeda, T. 1984. Methods in marine zooplankton ecology. A Wiley Int. Publication, John Wiley \& Sons. New York. 332pp.Pinca, S and S. Dallot. 1997. Zooplankton community structure in the Western Mediteranian Sea related to mesoscale hydrodynamics. Hydrobiologia, 365:127-142.

Pereira, L.C.C., Jimenez, J.A., Koening, M.L., Neto, F.F.P., Medeiros, C., \& Marinho da Costa, R. 2005. Effect of coastline properties and wastewater on plankton composition and distribution in a stressed environment on the north coast of Olinda-PE (Brasil). Brazilian Archives of Biology and Technology, 48(6):1013-1026.

Pranowo, W.S. 2012. Dinamika Upwelling dan Downwelling di Laut Arafuru dan Timor. Widyariset, 15(2): 415-423.

Pusat Penelitian Laut Dalam-Lembaga IImu Pengetahuan Indonesia dan Pemerintah Kabupaten seram Bagian Timur. 2017. Eksplorasi Pulau Geser dan Keffing. Laporan Penelitian. 110 hal.

Queiroga, H., Silva, C., Sorbe, J.C. \& Morgado F., 2005. Composition and distribution of zooplankton across an upwelling front on the northern Portuguese Coast during Summer. Hydrobiologia, 545:195-207.

Rakhesh, M., Raman, A.V., Kalavati, C., Subramanian, B.R., Sharma, V.S., Sunita B.E., \& Sateesh, N. 2008. Zooplankton community structute across an eddygenerated upwelling band close to a tropical bay-mangrove ecosystem. Marine Biology, 154:953-972.

Salonen, M., Urho L., \& Engstrom-Ost, J. 2009. Effect of turbidity and zooplankton availability on the condition and prey selection of pike larvae. Boreal Environment Research, 14: 981-989.
Sanchez-Velasco, L., \& Shirasago, B., 2000. Larval Feeding of Scomher japonicus (pisces: Scombridae) in the Gulf of California and Its Relation to Temperature and Chlorophyll Satellite Data. Pacific Science, 54 (2):127-136.

Sari, A.N., Hutabarat. S., \& Soedarsono, P. 2014. Struktur komunitas plankton pada padang lamun di pantai Pulau Panjang, Jepara. Diponegoro Journal of Maquares. Management of Aquatic Resources, 3(2):82-91.

Sediadi, A. 2004. Effek upwelling terhadap kelimpahan dan distribusi fitoplankton di perairan Laut Banda dan Sekitarnya. Makara Sains, 8(2):43-51.

Shimode, S., Toda, T., \& Kikuchi, T. 2006. Spatio-temporal changes in diversity and community structure of planktonic copepods in Sagami Bay, Japan. Marine Biolog, 148:581-597.

Suwartana, A. 1985. Sebaran kedalaman batas atas dan batas bawah lapisan termoklin di Laut Banda. Oseanologi di Indonesia 19.17-31.

Turner, J., Roncalli, V., Ciminiello, P.,. Aversano C.D., Fattorusso, E., tartaglione, L., Carotenuto, Y., Romano, G., Esposito, F., Miralto, A. \& lanora, A. 2012. Biogeographic effect of the Gulf of Mexico red tide dinoflagellate Karenia brevis on Mediteranian Copepods. Harmful Algae, 16:63-73

Varela, J.L., Intriago, K.M., Flores, J.C., \& Lucas-Pilozo, C.R. 2017. Feeding habits of juvenile yellowfin tuna (Thunnus albacares) in Ecuadorian waters assessed from stomach content and stable isotope analysis. Fisheries Research 194: 89-98.

Wijaya, R., Setiawan, F., \& Fitriani, S.D. 2011. Kajian fenomena arlindo di Laut Seram dan kaitannya dengan perubahan iklim global (la nina dan el nino. Makalah dipresentasikan dalam Seminar International Kelautan, BROK, Bali 9-10 Juni 2011.10 hal.

Wiadnyana, N. 1997. Variasi kelimpahan zooplankton di Teluk Kao, Halmahera (Maluku Utara). Oseanologi dan Limnologi di Indonesia 30:53-62.

Wyrkti, K. 1961. Physical Oceanography of the Southeast Asian waters. Naga rep. 2:195 pp. 
Yamaji, I.E. 1984. Illustrations of the marine plankton of Japan. Hoikusha Publishing Co., LTD, Japan. 536pp.

Zarkogiannis, S.D., Antonarakou, A., Tripati A., Kontakiotis, G., Mortyn, P.G., Drinia, H.\&
Greaves, M. 2019. Influence of surface ocean density on planktonic foraminifera calcification. Scientific Reports 9(1):533. 